\title{
SISTEM PAKAR KESEHATAN PADA IBU HAMIL BERBASIS MOBILE WEBSITE
}

\author{
Umi Setiyani, Arkhan Subari \\ Program Studi Diploma III Teknik Elektro \\ Fakultas Teknik Universitas Diponegoro
}

\begin{abstract}
Umi Setiyani, Arkhan Subari, in this paper explain that the maternal mortality rate in Indonesia is still high, every 1 hour, 2 maternal death. Lack of information about the health of pregnant women, to be one cause. By utilizing the WAP ( Wireless Application Protocol) and expert systems can be made to maternal health expert system -based mobile website. Maternal health expert system is able to diagnose 15 to 61 illnesses symptoms often suffered by pregnant women. Diagnosis of the disease is designed using forward chaining inference engine with the aid of decision tables and decision trees. In addition the system is also able to calculate the daily calories needed by pregnant women using cooper. So with this system can help pregnant mothers to know their health condition.
\end{abstract}

Keywords : expert system, Wireless Application Protocol, the health of pregnant women.

\section{PENDAHULUAN \\ Latar Belakang}

Tingkat kematian ibu saat melahirkan di Indonesia masih tinggi, setiap 1 jam, 2 ibu melahirkan meninggal dunia. Menurut Deputi Bidang Keluarga Sejahtera dan Pemberdayaan Keluarga (KSPK) BKKBN, DR Sudibyo Alimoesa, jumlah yang ditargetkan 102 kematian dari 100.000 kelahiran pada tahun 2015. Angka kematian Ibu yang masih tinggi ini diakibatkan kurangnya pengetahuan mengenai kesehatan kehamilan. Banyak hal penting seperti masalah nutrisi yang cukup, gaya hidup, olahraga dan penyakit yang kurang diperhatikan. Padahal jika hal-hal itu diperhatikan maka proses melahirkan akan menjadi lebih baik. Peran pemerintah juga belum optimal dalam penyampaian informasi mengenai kesehatan kehamilan sehingga berdampak pada angka kematian ibu yang semakin tinggi. Program internet ini didukung dengan adanya teknologi WAP (Wireless Application Protokol) atau mobile website yang mampu menampilkan halaman website pada ponsel dengan menggunakan bahasa markup XHTML dan WCSS. Dengan menggunakan ponsel dapat diakses berbagai informasi, termasuk informasi tentang kesehatan ibu hamil dengan sistem pakar seperti layaknya berkonsultasi dengan seorang dokter atau bidan.

\section{Permasalahan}

Permasalahan yang akan dibahas dalam penelitian ini adalah sebagai berikut :

- Sistem Pakar dengan menggunakan metode forward chaining

- Data-data penunjang penyakit pada ibu hamil yang digunakan hanya pada saat masa kehamilan saja dan penyakit dengan gejala tanpa harus cek ke laboratorium.

- Penyimpanan data-data penunjang
- Bahasa pemrograman yang digunakan menggunakan XHTML,CSS dan PHP

- Web Server yang digunakan adalah Apache

- Emulator yang digunakan adalah Opera Mobile Emulator

\section{SISTEM PAKAR}

Sistem pakar adalah sistem berbasis komputer yang menggunakan pengetahuan, fakta, dan teknik penalaran dalam pemecahan masalah yang biasanya hanya dapat dipecahkan oleh seorang pakar dalam bidang tersebut.

\section{Struktur Sistem Pakar}

Sistem pakar disusun berdasarkan struktur sebagai berikut :

- Antarmuka Pengguna (User Interface)

User interface merupakan mekanisme yang digunakan oleh pengguna dan sistem pakar untuk berkomunikasi.

- Basis Pengetahuan

Basis pengetahuan mengandung pengetahuan untuk pemahaman, formulasi dan penyelesaian masalah.

- Mesin Inferensi

Komponen ini mengandung mekanisme pola pikir dan penalaran yang digunakan oleh pakar dalam menyelesaikan suatu masalah.

- Basis Data(Data Base)

Basis data terdiri atas semua fakta yang diperlukan, dimana fakta-fakta tersebut digunakan untuk memenuhi kondisi dari kaidah-kaidah dalam sistem. Basis data menyimpan semua fakta, baik fakta awal pada saat sistem mulai beroperasi, maupun faktafakta yang diperoleh pada saat proses penarikan kesimpulan sedang dilaksanakan. menggunakan database MySQL 


\section{Tabel Keputusan}

Tabel keputusan adalah tabel yang digunakan sebagai alat bantu untuk menyelesaikan logika dalam program. Algoritma yang berisi keputusan bertingkat yang banyak sekali sangat sulit digambarkan langsung dengan structured English atau pseudocode dan dapat dibuat terlebih dahulu dengan menggunakan tabel keputusan. Gambar 1 merupakan contoh struktur tabel keputusan

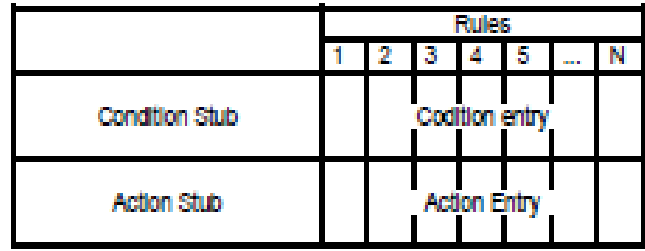

Gambar 1. Struktur Tabel Keputusan

\section{Pohon Keputusan (Decision Tree)}

Pohon keputusan adalah cara merepresentasikan kumpulan aturan yang mengacu ke suatu nilai atau kelas. Misalnya kita bisa mengklasifikasikan suatu proposal pinjaman uang memiliki resiko baik atau buruk. Gambar 2 memperlihatkan decision tree sederhana: decision node, branches and leaves.

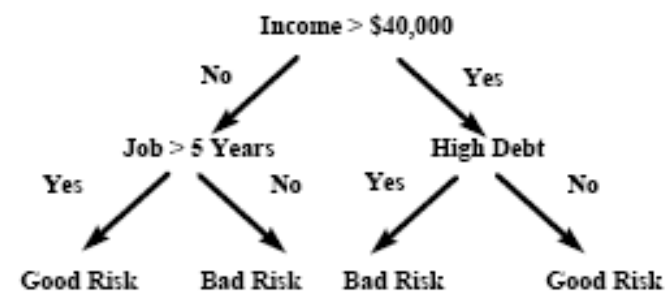

Gambar 2. Classification tree sederhana

\section{Inferencing Rule dengan metode backward chaining dan froward chaining}

Inferensi merupakan proses untuk menghasilkan informasi dari fakta yang diketahui atau diasumsikan. Inferensi dari fakta yang diketahui atau diasumsikan. Inferensi adalah konklusi logis (logical conclusion) atau implikasi berdasarkan informasi yang tersedia.

Ada dua metode inferensi yang penting dalam sistem pakar, yaitu runut maju (backward chaining) dan runut balik (backward chaining).

- $\quad$ Runut Maju (Forward Chaining)

Runut maju berarti menggunakan himpunan atau kondisi-aksi. Dalam metode ini, data digunakan kemudian aturan tersebut dijalankan. Mungkin proses menambahkan data ke memori kerja. Proses diulang sampai ditemukan suatu hasil.

- $\quad$ Runut Balik (Backward Chaining)

Runut balik merupakan metode penalaran kebalikan dari runut maju. Dalam runut balik, penalaran dimulai dengan tujuan merunut balik ke jalur yang akan mengarahkan ke tujuan tersebut.

\section{XHTML MP}

XHTML MP (eXtensible HyperText Markup Language Mobile Profile) adalah bahasa markup yang didefinisikan dalam WAP 2.0. WAP 2.0 adalah spesifikasi mobile service terbaru yang dibuat oleh WAP Forum (sekarang menjadi Open Mobile Alliance [OMA]). Spesifikasi dari WAP CSS (WAP Cascading Style Sheet atau WCSS) juga didefinisikan di dalam WAP 2.0. WAP CSS adalah seperangkat dengan XHTML, keduanya digunakan bersama-sama. Dengan menggunakan WAP CSS kita dapat dengan mudah mengubah dan memformat tampilan halaman XHTML MP.

\section{WAPCSS}

WCSS (WAP Cascading Style Sheet atau WAP CSS ) adalah versi mobile dari CSS, yang merupakan bagian dari CSS2 ditambah dengan beberapa spesifikasi ekstensi. Dalam aplikasi perangkat mobile WAP 2.0, XHTML MP digunakan untuk menentukan isi dan WCSS digunakan untuk mendeskripsikan bagaimana menampilkan isi dalam browser WAP.

\section{PERANCANGAN SISTEM}

Pada perancangan sistem pakar kesehatan ibu hamil berbasis mobile website ini terdiri atas beberapa tahapan yaitu :

- Perancangan Data

Perancangan data dalam sistem ini adalah perancangan data-data yang dibutuhkan oleh sistem. Data untuk aplikasi ini diperoleh melalui buku, media internet dan konsultasi dengan pakar di bidang kebidanan.

- Perancangan Basis Data

Database sistem dirancang dengan menggunakan aplikasi MySQL. Pada Diagnosa penyakit, perancangan basis data berfungsi untuk menyimpan data-data penunjang sebagai inputan sistem yang kemudian akan diolah menjadi data output sistem. Sedangkan pada konsultasi gizi basis data berfungsi untuk menyimpan data-data penunjang masukkan dan keluaran sistem.

- Perancangan Mesin Inferensi Perancangan mesin inferensi bertujuan untuk memperoleh penyakit yang diderita oleh user dan solusi dari penyakit tersebut.

- Perancangan Diagram Alir

Perancangan diagram alir meliputi diagram alir keseluruhan sistem dan diagram alir tiap-tiap menu pada sistem.

- Perancangan Antarmuka Sistem

Antarmuka sistem dirancang dengan menggunakan aplikasi Adobe Dreamweaver CS3. Dengan bahasa pemrograman XHTML MP, WAP CSS dan PHP. 


\section{PENGUJIAN DAN ANALISA}

Pengujian ini dilakukan dengan mengoperasikan keseluruhan sistem meliputi halaman utama, halaman about, halaman konsultasi penyakit dan halaman konsultasi gizi.

\section{Halaman Utama}

Pada saat pertama kali user menjalankan sistem maka akan tampil halaman utama yang berisi penjelasan mengenai sistem yang dibuat dan kegunaannya. Pada halaman utama juga terdapat menu-menu seperti menu konsultasi penyakit, konsultasi gizi dan halaman about. Jika pengguna memilih halaman konsultasi penyakit maka sistem akan menuju ke halaman konsultasi penyakit. Jika pengguna memilih menu konsultasi gizi maka sistem akan menuju ke halaman konsultasi gizi, dan begitu juga ketika pengguna memilih halaman about maka pengguna akan diarahkan sistem menuju halaman about yang berisi penjelasan mengenai pembuat sistem. Gambar 3 menunjukkan tampilan halaman utama, sedangkan gambar 4 menunjukkan tampilan halaman about.

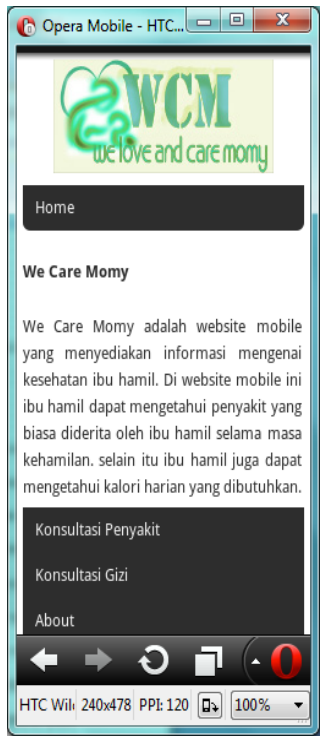

Gambar 3. Tampilan Halaman Utama

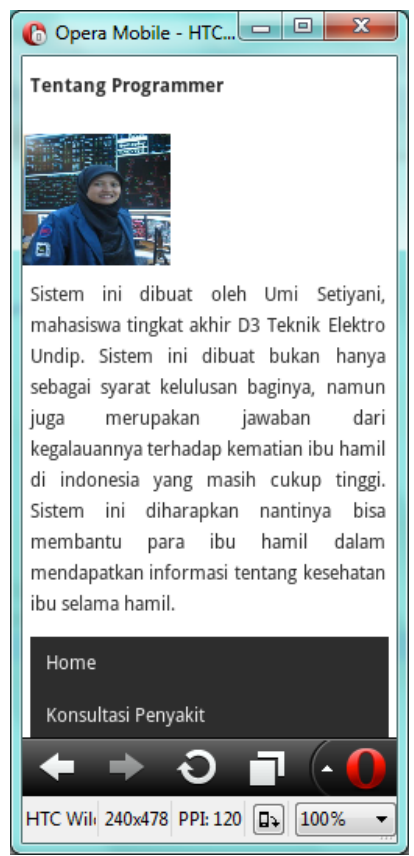

Gambar 4. Tampilan Halaman About

\section{Halaman Diagnosa Penyakit}

Pada halaman ini terjadi proses forward chaining. Pada proses ini user pertama-tama akan diberi pertanyaan mengenai gejala yang paling umum dialami untuk semua jenis penyakit pada ibu hamil. User diberikan pilihan jawaban, pilihan jawaban 'Ya' untuk representasi user mengalami gejala tersebut dan jawaban 'Tidak' untuk representasi user tidak mengalami gejala tersebut. Tampilan halaman diagnose penyakit dan hasilnya ditunjukkan pada gambar 5 dan 6 .

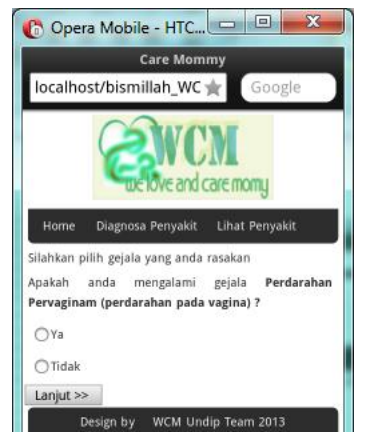

Gambar 5. Halaman diagnosa penyakit

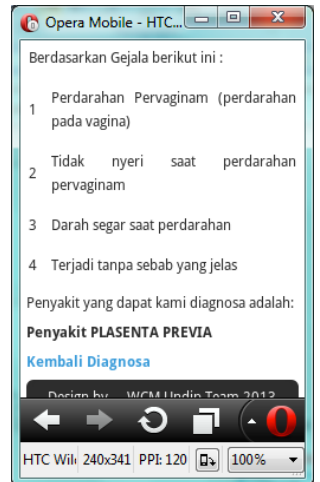

Gambar 6. Hasil kesimpulan diagnosa penyakit 
Dari pengujian halaman diagnosa penyakit, penyakit yang dapat terdeteksi adalah 15 penyakit, dan 61 gejala penyakit. Pada gambar 4.4 terdapat kesimpulan penyakit plasenta previa yang memiliki 4 buah gejala, yakni gejala perdarahan pervaginam (perdarahan pada vagina), tidak nyeri saat perdarahan pervaginam, darah segar saat perdarahan dan terjadi tanpa sebab yang jelas.

\section{Halaman Lihat Penyakit}

Pada halaman ini user akan diberikan pilihan mengenai berbagai penyakit yang ada di dalam sistem. Lalu ketika user mengklik link detail, akan ditampilkan penjelasan mengenai penyakit yang dipilih. Halaman lihat penyakit dan detailnya ditunjukkan pada gambar 7 dan 8 .

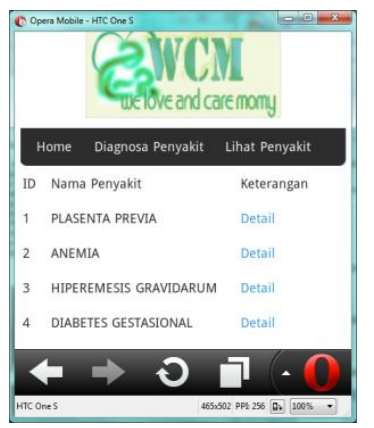

Gambar 7. Halaman lihat penyakit

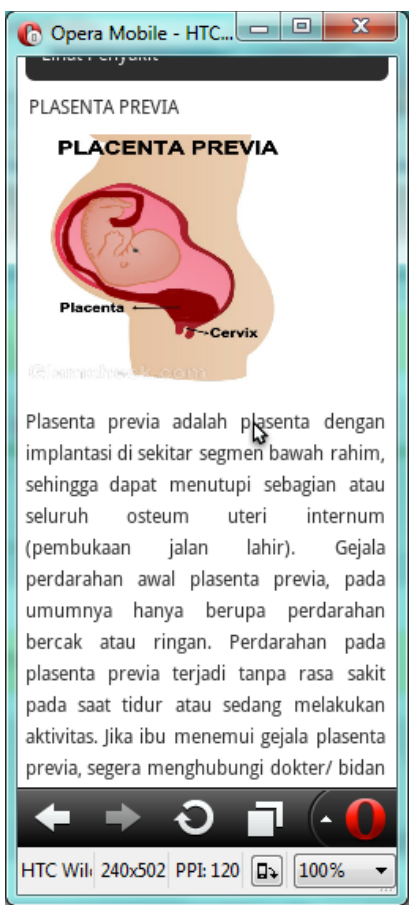

Gambar 8. Halaman detail penyakit

\section{Halaman Konsultasi Gizi}

Pada halaman konsultasi gizi, user akan ditampilkan halaman untuk memasukkan data-data dari ibu hamil (user) berupa tinggi badan dalam $\mathrm{cm}$, usia kehamilan dalam minggu, jumlah jam tidur yakni 8 atau 7 jam dan jenis aktivitas yang dilakukan oleh ibu hamil (user) yakni aktivitas berat, sedang, ringan, sangat ringan dan lainnya.

Ketika ibu hamil mengklik tombol lihat kalori, maka sistem akan melakukan proses penghitungan kalori dengan menggunakan metode chooper. Lalu setelah data masukkan dari user diproses, akan ditampilkan kalori yang dibutuhkan ibu hamil dalam bentuk gram (karbohidrat, lemak dan protein). Halaman konsultasi gizi dan hasilnya ditunjukkan pada gambar 9 dan 10 .

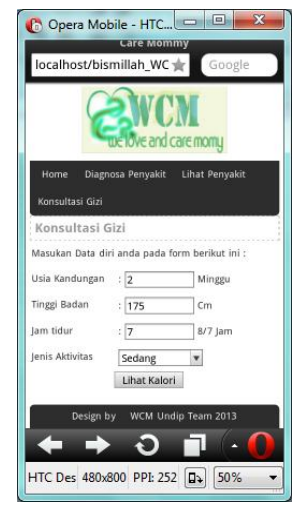

Gambar 9. Halaman konsultasi gizi

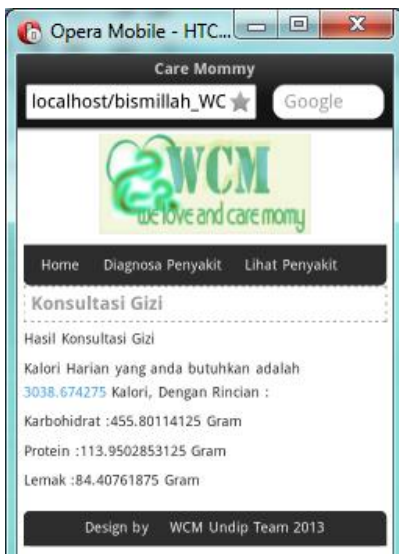

Gambar 10. Halaman hasil konsultasi gizi

Dari pengujian yang dilakukan sistem mampu melakukan perhitungan kalori berdasarkan masukan-masukan yang ada pada form diagnosa gizi. Hasil dari kalori yang ditampilkan sesuai dengan rumus yang ada pada metode cooper. Pada tabel 4.2 terdapat perbandingan dari hasil pengujian perhitungan gizi pada aplikasi dan perhitungan gizi dengan rumus.

\section{Kesimpulan}

Dari pengujian yang telah dilakukan, maka dapat diberikan kesimpulan sebagai berikut :

- Aplikasi yang dibuat mampu melakukan penalaran dengan alur forward chaining dengan bantuan pohon keputusan dan tabel keputusan

- Basis data yang digunakan adalah MySQL, karena merupakan satu-kesatuan dengan aplikasi server yakni apache. Pada basis data 
yang digunakan terdapat 5 buah tabel, yaitu tabel penyakit, gejala, gejala_penyakit, question dan gizi.

- Bahasa pemrograman yang digunakan berhasil diaplikasikan di dalam sistem dan dapat berjalan dengan baik.XHTML dan WCSS yang digunakan untuk mendesain tampilan dapat berjalan dengan baik ketika dijalankan pada emulator dan pada perangkat mobile

- Bahasa pemrograman PHP juga dapat berjalan dengan baik ketika aplikasi dijalankan secara lokal maupun melalui perangkat mobile.

- Program dapat berjalan dengan baik dengan menggunakan opera mobile emulator dengan server lokal yakni apache.

- Representasi pengetahuan yang digunakan pada aplikasi ini adalah kaidah produksi, dimana untuk mengambil keputusan kita menggunakan kaidah jika -maka (if-then).

- $\quad$ Sistem yang dibuat mampu untuk mendiagnosa 15 penyakit dengan 61 gejala pada ibu hamil. Parameter masukkan berupa gejala-gejala yang dialami oleh ibu hamil yang diproses oleh sistem lalu ditampilkan penyakit yang diderita oleh ibu hamil berdasarkan gejala yang dialami.

- Penghitungan gizi pada ibu hamil dengan metode cooper dapat menghasilkan kalori yang dibutuhkan oleh ibu hamil. Dengan parameter masukkan usia kandungan dalam minggu, tinggi badan ibu dalam $\mathrm{Cm}$, jumlah jam tidur pada ibu hamil (7-8 jam), dan jenis aktifitas yang dilakukan oleh ibu hamil.

\section{DAFTAR PUSTAKA}

1. Natalia, Deasy Astrid. 2006. Pembangunan Sistem Pakar pada Perangkat Mobile dengan WML dan PHP untuk Penyakit Paru pada Anak. Surabaya

2. Broto, Adi Sadewo.2010. Perancangan dan Impelentasi Sistem Pakar untuk Analisa Penyakit Dalam. Semarang : Unversitas Diponegoro.

3. Giarratano, J.C \& Rilley G. 1994. Expert Systems: Principles and Programming, $2^{\text {sd }}$ edition. USA : PWS Publishing Co.

4. Kusrini. 2008. Aplikasi Sistem Pakar. Yogyakarta : Penerbit Andi.

5. Martin dan Oxman dalam Kusrini. 2006. Aplikasi Sistem Pakar. Yogyakarta : Penerbit Andi.

6. Turban, E. 1995. Decision Support System dan Expert System. USA :Prentice Hall International Inc
7. Mulyono, Djoko. 2008. Pembangunan Sistem Pakar pada Perangkat Mobile dengan WML dan PHP untuk Menemukan Penyebab Kerusakan Mesin Isuzu Panther. Semarang : Unaki

8. Surono, dkk.2009. Bahasa Indonesia Untuk Perguruan Tinggi. Semarang: Fasindo Press

9. Mc Leod dalam Turban,E. 1995. Decision Support System dan Expert System. USA : Prentice Hall International Inc.

10. Turban dalam Mulyono, Djoko. 2008. Pembangunan Sistem Pakar pada Perangkat Mobile dengan WML dan PHP untuk Menemukan Penyebab Kerusakan Mesin Isuzu Panther. Semarang : Unaki

11. Wilson dalam Kusrini. 2006. Aplikasi Sistem Pakar. Yogyakarta : Penerbit Andi.

12. Giarratano dan Rilley dalam Kusrini. 2006. Aplikasi Sistem Pakar. Yogyakarta : Penerbit Andi.

13. Solichin,Achmad. 2013. Pemrograman Web dengan PHP dan MySQL. Jakarta: UBL

14. Juman, Kundang K. 2009. Komunikasi Multimedia.Jakarta

15. Nokia. 2002. XHTML Guidlines. Finlandia : Nokia Corporation.

16. Priyandari. 2013. Tutorial Database II, Mengenal RDBMS MySQL, http://blog.priyandari.net/2013/tutorialdatabase-ii-mengenal-rdbms-mysql-1/, diiakses tanggal 15 Agustus 2013.

17. Anonim. 2013. XHTML MP (eXtensible HyperText Markup Language Mobile Profile). http://www.developesrhome.com/, diakses tanggal 4 Juni 2013

18. Dinkes Jateng. 2011. Profil Kesehatan Jateng 2011. Semarang : Dinkes Jateng

19. Setiawan (Ed). 1998. Ilmu Kebidanan, Penyakit Kandungan, dan Keluarga Berencana. Finlandia: Penerbit Buku Kedokteran EGC

20. Wiknjosastro, Hanifa. 2005. Ilmu Kandungan. Jakarta : Yayasan Bina Pustaka Sarwono Prawirohardjo.

21. Saifuddin, Abdul Bari. 2006. Buku Acuan Nasional Pelayanan Kesehatan Maternal dan Neonatal. Jakarta : Yayasan Bina Pustaka Sarwono Prawirohardjo.

22. Poedyasmoro, SKM. 2005. Buku Praktisi Ahli Gizi (Buku Kuliah Politeknik Kesehatan Malang). Malang

23. Wahyudi, doni. 2004. Data Mining Email. Bandung 